\title{
The protective effects of glycyrrhizic acid on heavy metal ions-induced reproductive toxicity in Chinese hamster ovary cells
}

\author{
Liang Gao ${ }^{\mathrm{a}}$, Pai Liu ${ }^{\mathrm{b}}$, Tianqi Du ${ }^{\mathrm{a}}$, Jian Yin ${ }^{\mathrm{b}, \mathrm{c}, *}$, Hong $\mathrm{Li}^{\mathrm{a}, *}$ \\ a Center of Reproduction and Genetics, Affiliated Suzhou Hospital of Nanjing Medical University, Suzhou \\ Municipal Hospital, Suzhou 215002 China \\ b CAS Key Laboratory of Biomedical Diagnostics, \\ Suzhou Institute of Biomedical Engineering and Technology, Chinese Academy of Science, Suzhou \\ 215163 China \\ c Jinan Guo Ke Medical Technology Development Co., Ltd, Jinan 250100 China
}

*Corresponding authors, e-mail: yinj@sibet.ac.cn, hongliszivf@163.com

Received 10 Aug 2020

Accepted 26 Apr 2021

\begin{abstract}
In this work, Chinese hamster ovary (CHO) cells were used to examine the protective effects of glycyrrhizic acid (GA) on the reproductive toxicity of heavy metal ions, including $\mathrm{Cd}^{2+}$ and $\mathrm{Cu}^{2+}$. As a result, both metal ions induced significant toxicity in $\mathrm{CHO}$ cells after 48 -h treatment, as revealed by a severe decrease in cell viability. GA and glutathione (GSH) largely reduced the toxicity caused by $\mathrm{Cd}^{2+}$ and $\mathrm{Cu}^{2+}$, which could be due to their recovery of GSH levels and superoxide dismutase (SOD) activities in CHO cells. In addition, GA and GSH significantly up-regulated the gene expressions of glutathione S-transferase (gst), sod, and heme oxygenase (ho)-1, which could be another explanation for their protective effects. More importantly, GA exhibited comparable protective effects as GSH but at much lower concentrations (50-100 $\mu \mathrm{M}$ v.s. 500-1000 $\mu \mathrm{M})$. Therefore, GA could be effective for the alleviation of reproductive toxicity of $\mathrm{Cd}^{2+} / \mathrm{Cu}^{2+}$, which needs further investigation in animal models.
\end{abstract}

KEYWORDS: Chinese hamster ovary cells, $\mathrm{Cd}^{2+}, \mathrm{Cu}^{2+}$, glycyrrhizic acid, oxidative stress

\section{INTRODUCTION}

So far, the toxicity of heavy metal ions, like $\mathrm{Cd}^{2+}$ and $\mathrm{Cu}^{2+}$, are being paid more and more attentions, as they are nondegradable and inevitably released from human activities like mining, smelting, and manufacturing [1-4]. Free $\mathrm{Cd}^{2+}$ and $\mathrm{Cu}^{2+}$ have been found to be toxic to rat, mice, and various fishes; causing weight loss, developmental abnormality, and even death [5-7]. More importantly, both metal ions can significantly alter the reproductive capability of treated animals without causing significant damages [8]. In this respect, it is important to illustrate the mechanism on the reproductive toxicity of metal ions and to screen potential detoxification agents.

Various experiments have been conducted on the reproductive toxicity of metal ions. Their results indicated that the toxicity might occur in testicle, fetus, spermatozoa, and ovary [9-13]. The involving mechanisms, like impairment of steroid hormones and cell apoptosis, have been proposed in different literatures, but oxidative stress was most widely accepted as the common reason $[14,15]$. Production of glutathione (GSH) and the induction of anti-oxidative enzymes like glutathione Stransferase (GST), catalase (CAT), superoxide dismutase (SOD), and heme oxygenase (HO)-1 were important in the protection of organisms from the toxicity of metal ions $[16,17]$. Unfortunately, significant toxicity still occurred when the oxidative stress exceeded the limits of these anti-oxidative systems. In this respect, it should be useful to develop reducing agents for the treatment of metal ions-induced reproductive toxicity.

Nowadays, many herbal medicines have been tried for the treatment of reproductive diseases, and most of them have detoxification functions $[18,19]$. Liquorice is one of such herbs to reduce chemical-induced reproductive toxicity in animals $[20,21]$. The main bioactive compound of liquorice, glycyrrhizic acid (GA), is well known for its ability to eliminate reactive free radicals and to stabilize cell membrane $[10,22]$. Several studies revealed 
that GA exhibited a greater protective effect than liquorice $[23,24]$. Nevertheless, the use of GA mostly focuses on the reduction of drug-induced toxicity, and its effects on the toxicity of metal ions are still rare, especially the reproductive toxicity.

The present study aimed to investigate the effects of GA on the reproductive toxicity of heavy metal ions, including $\mathrm{Cd}^{2+}$ and $\mathrm{Cu}^{2+}$, in Chinese hamster ovary (CHO) cells. To assess the relating mechanism in such interactions, the alteration of glutathione (GSH) level, superoxide dismutase (SOD) activity, apoptosis status, as well as the expressions of anti-oxidative enzymes caused by metal ions and metal ions-GA/GSH mixtures were evaluated. GSH was used here as a positive control, since it was the major antioxidant produced by the cells, protecting them from free radicals [25].

\section{MATERIALS AND METHODS}

\section{Chemicals}

CHO cells were purchased from Shanghai Cell Bank, Chinese Academy of Sciences (Shanghai, China). Dulbecco's Modified Eagle's Medium (DMEM) and fetal bovine serum were purchased from Gibco (Gaithersburg, USA). Methyl thiazolyl tetrazolium (MTT), glutathione (GSH), and glycyrrhizic acid (GA) were got from Sigma-Aldrich (St Louis, MO, USA). $\mathrm{CuCl}_{2}$ and $\mathrm{CdCl}_{2}$ were from Sinopharm Chemical Reagent Co., Ltd. (Shanghai, China). Annexin V-FITC apoptosis detection kit and enhanced cell counting kit-8 (CCK-8) were purchased from Shanghai Biyuntian Biotechnology Company (Shanghai, China). First strand cDNA synthesis and qPCR kits (SYBR Green Method) were got from Thermo Fisher Scientific (San Jose, CA, USA). Primers were synthesized by Genewiz (Suzhou, China). Ultrapure water used in this study was produced by the Milli-Q Water System (Millipore Corp., Bedford, MA, USA). All other chemicals purchased from local reagent companies and of reagent grade.

\section{Cell treatment}

$\mathrm{CHO}$ cells were cultured in 24-well plates and maintained in DMEM medium containing $10 \%$ fetal bovine serum. The cells were kept at $37^{\circ} \mathrm{C}, 5 \% \mathrm{CO}_{2}$ in a humidified atmosphere until reaching $80 \%$ confluence. After then, cells were washed with phosphate buffer solution (PBS, $\mathrm{PH}=7.4$ ) and treated with medium containing a series of concentrations of $\mathrm{CuCl}_{2}, \mathrm{CdCl}_{2}$, and $\mathrm{CuCl}_{2} / \mathrm{CdCl}_{2}+\mathrm{GA} / \mathrm{GSH}$.

To investigate the cytotoxicity of heavy metal ions, $\mathrm{CHO}$ cells were treated with $\mathrm{CdCl}_{2}$ and $\mathrm{CuCl}_{2}$ at the concentrations of $0,0.01,0.1,1,10,100$, and $1000 \mu \mathrm{M}$. Cell viability was determined after $48 \mathrm{~h}$ treatment. To determine the apoptosis status, oxidative stress level, and transcriptional alterations caused by each treatment, cells were washed with PBS and cultured in $1 \mathrm{ml}$ medium containing $\mathrm{CuCl}_{2}$ $(50 \mu \mathrm{M}) / \mathrm{CdCl}_{2}(5 \mu \mathrm{M})$ with or without GA $(50$ and $100 \mu \mathrm{M}) / \mathrm{GSH}(500$ and $1000 \mu \mathrm{M})$. After $48 \mathrm{~h}$ treatment, cells in each group were collected for further analysis.

\section{Cell viability assay}

Cell viability was evaluated with CCK-8 assay according to the manufactures' instructions. After each treatment, cells in each well were washed with PBS and treated with $0.5 \mathrm{ml}$ DMEM medium containing $10 \mu \mathrm{l}$ of CCK-8 reagents. After 2-h incubation at $37^{\circ} \mathrm{C}$, the optical density of each well at $450 \mathrm{~nm}$ was detected with a Synergy 2 microplate reader (BioTek Instruments, Winooski, VT, USA). Viability of treated cells was expressed as the percentage of untreated control.

\section{GSH and SOD detection}

At $48 \mathrm{~h}$, cells in each group were washed with PBS, scraped by a rubber policeman, and collected in $500 \mu \mathrm{l}$ PBS. After that, the collected cells were lysed by sonication $(40 \mathrm{kHz}, 900 \mathrm{~W}, 5 \mathrm{~s})$ twice. Subsequently, the lysates were centrifuged $\left(10000 \mathrm{~g}, 4^{\circ} \mathrm{C}\right.$, $10 \mathrm{~min}$ ) to get rid of cell fragments and stored at $4{ }^{\circ} \mathrm{C}$ for further analysis. The reduced GSH levels and SOD activities in each group were then detected using commercial kits (Beyotime Institute of Biotechnology, Jiangsu, China) as described before [26]. Among them, GSH levels were determined by the formation of 5-thio-2-nitrobenzoic acid $(412 \mathrm{~nm})$ and expressed as pmol of GSH presented in $10^{6}$ cells (pmol/10 ${ }^{6}$ cells). SOD activities were detected by nitroblue tetrazolium/riboflavin photometric quantitative methods $(420 \mathrm{~nm})$. The obtained results were expressed as $\mathrm{U} / 10^{6}$ cells, as well.

\section{Apoptosis detection}

After each treatment, cells in 24-well plates were detached with Trypsin-EDTA solution (0.25\% Trypsin and $0.02 \%$ EDTA, $\mathrm{m} / \mathrm{v}$, dissolved in PBS). The collected cells from each well were suspended in $0.5 \mathrm{ml}$ PBS and stained with Annexin V-FITC apoptosis detection kit for $10 \mathrm{~min}$. The fluorescence in each group was detected by a Synergy 2 microplate reader (BioTek Instruments, Winooski, VT, USA) at $485 / 530 \mathrm{~nm}$. The obtained results were normal- 
ized to cell viability and expressed as multiples of untreated control.

\section{RT-PCR analysis}

Total RNA was extracted from $\mathrm{CHO}$ cells with commercial kits (Axygen Scientific, Inc., USA) after each treatment. The quality of RNA was determined by 260/280 nm absorption using a NanoDrop 2000 spectrophotometer (Thermo Fisher Scientific, Inc., USA). The obtained RNA was reversely transcribed into cDNA and amplified with commercial kits according to the manufactures' instructions. PCR reactions were conducted in a real-time PCR system (Stepone Plus, Applied Biosystems, CA, USA) with cycling parameters of $95^{\circ} \mathrm{C}$ for $30 \mathrm{~s}, 40$ cycles of $95^{\circ} \mathrm{C}$, for $5 \mathrm{~s}$ and $60^{\circ} \mathrm{C}$ for $34 \mathrm{~s}$. Relative expressions of each gene were obtained with $2^{-\Delta \Delta C(t)}$ method and normalized to untreated control groups. All the primers are shown in Table $S 1$ and $\beta$-actin was used as a house-keeping gene [5].

\section{Statistical analysis}

All the results in this experiment were the average values (mean $\pm S D$ ) of three independent experiments. Statistical analysis was carried out with SPSS v 15.0 (SPSS Inc., Chicago, Illinois, USA). One-way ANOVA post-hoc tests were used to analyze the differences among multiple groups. Dunnett's test was applied for the comparison between control and treated groups. Significance was obtained when $p<0.05$.

\section{RESULTS}

\section{Toxicity of $\mathrm{Cd}^{2+}$ and $\mathrm{Cu}^{2+}$}

After exposure to $\mathrm{Cd}^{2+}$ and $\mathrm{Cu}^{2+}$ for $48 \mathrm{~h}$, concentration-dependent damages in $\mathrm{CHO}$ cells were noticed (Fig. 1). A slight reduction of cell viability was found after the treatment of $10 \mu \mathrm{M}$ $\mathrm{Cd}^{2+}$ for $48 \mathrm{~h}$, which was $80.10 \pm 6.73 \%$. Nearly all the cells died after the exposure of $500 \mu \mathrm{M}$ $\mathrm{Cd}^{2+}$ (Fig. 1A). On the other hand, the survival rate of $\mathrm{CHO}$ cells after the treatment of 10 $1000 \mu \mathrm{M} \mathrm{Cu}{ }^{2+}$ decreased from $99.43 \pm 5.14 \%$ to $1.04 \pm 0.43 \%$ (Fig. 1B). According to the concentration-response curve, median-lethal concentrations were determined to be $42.5 \mu \mathrm{M}$ and $287.5 \mu \mathrm{M}$ for $\mathrm{Cd}^{2+}$ and $\mathrm{Cu}^{2+}$, respectively. These concentrations were also used in the subsequent experiments.
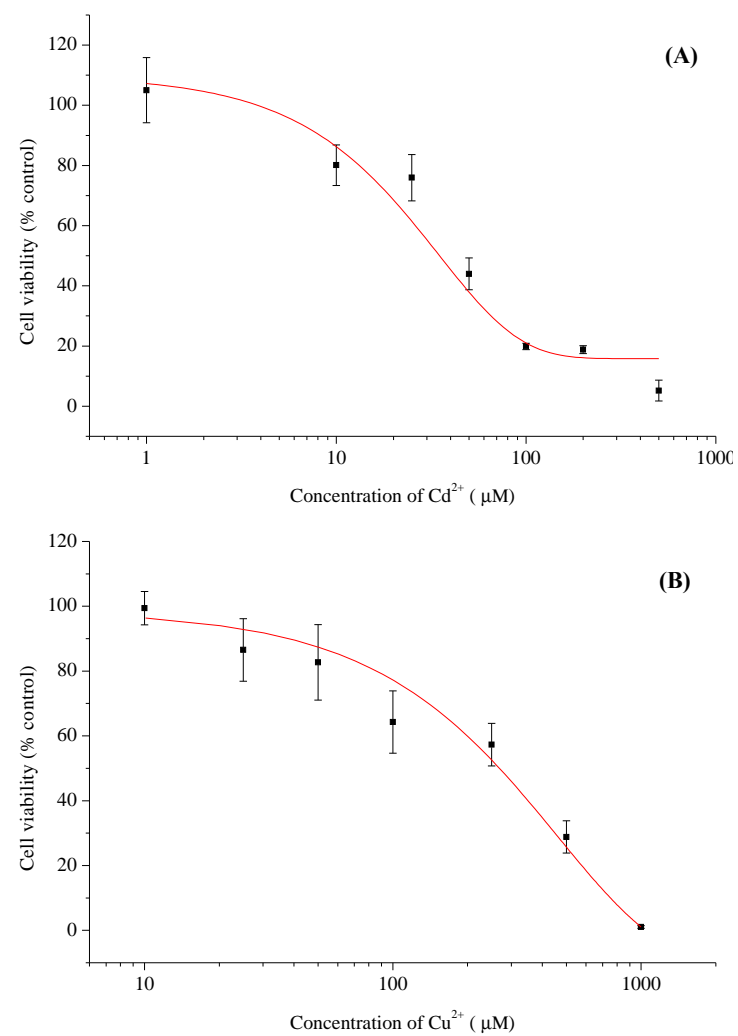

Fig. 1 Concentration-dependent mortality caused by $\mathrm{Cd}^{2+}$ and $\mathrm{Cu}^{2+}$ in $\mathrm{CHO}$ cells. After reaching $80 \%$ confluence, cells in each group were treated with different concentrations of $\mathrm{CdCl}_{2}$ and $\mathrm{CdCl}_{2}$. Cell viability was determined after $48 \mathrm{~h}$ treatment using MTT assay and expressed as the percentage of untreated control groups. Data were represented as mean values \pm SD of three independent experiments. ${ }^{*} p<0.05, * * p<0.01$, $* * * p<0.001$ compared with untreated control.

\section{Effects of GA and GSH on the toxicity of metal ions}

As shown in Fig. 2, GA (50 and $100 \mu \mathrm{M}$ ) and GSH (500 and $1000 \mu \mathrm{M}$ ) significantly reduced metal ions-induced cell death, in a concentrationdependent manner. For instance, $42.5 \mu \mathrm{M} \mathrm{Cd}^{2+}$ caused a cell viability of $50.28 \pm 8.68 \%$, and the values increased to $75.92 \pm 8.68 \%$ and $92.36 \pm 8.02 \%$ after the co-exposure of 50 and $100 \mu \mathrm{M} \mathrm{GA}$, respectively. The recovering effects of GSH were more obvious, as the cell viability were $103.57 \pm 13.06 \%$ and $106.07 \pm 10.04 \%$ after the addition of 500 and $1000 \mu \mathrm{M}$ GSH, respectively. Similar phenomena were also found with $\mathrm{Cu}^{2+}$, and the highest cell viability was $93.52 \pm 2.83 \%$, after the co-treatment 

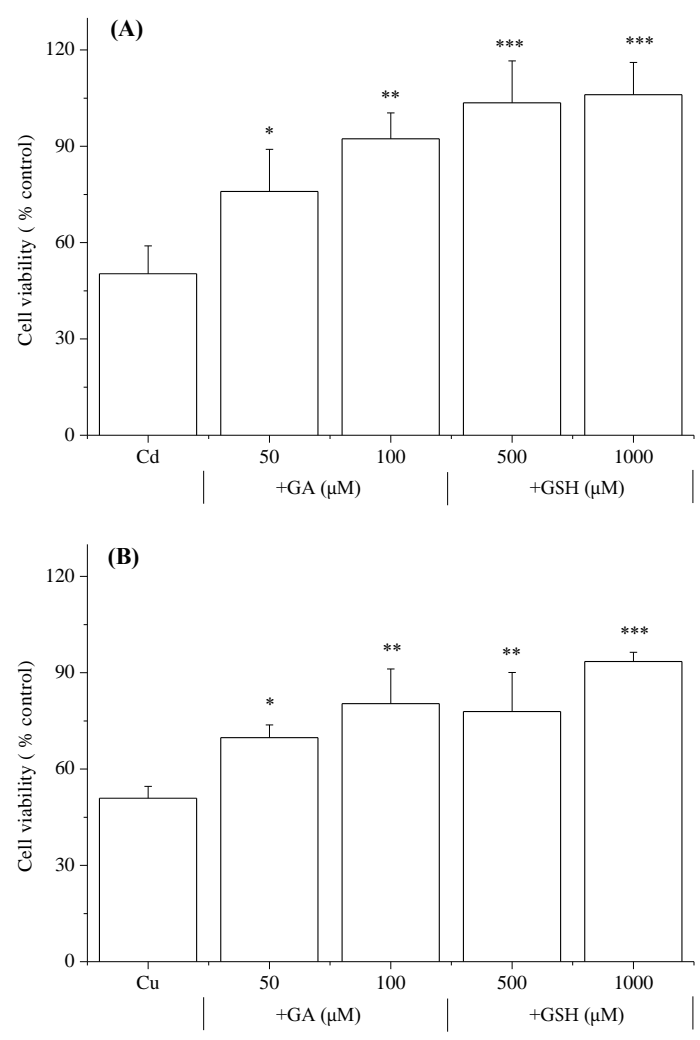

Fig. 2 Effects of GA and GSH on metal ions-induced death in CHO cells. GA and GSH were added together with metal ions, and cell viability were recorded at $48 \mathrm{~h}$ using MTT assay and expressed as the percentage of untreated control groups. Data were represented as mean values \pm SD of three independent experiments. ${ }^{*} p<0.05$, $* * p<0.01, * * * p<0.001$ compared with groups treated with metal ions alone.

of $287.5 \mu \mathrm{M} \mathrm{Cu}^{2+}$ and $1000 \mu \mathrm{M} \mathrm{GSH}$.

\section{Changes in the levels of GSH and SOD}

To illustrate the possible detoxification mechanisms of GA and GSH, alteration of reduced GSH level and SOD activities were evaluated after the treatment of metal ions with or without GA/GSH (Fig. 3). As a result, both $\mathrm{Cd}^{2+}$ and $\mathrm{Cu}^{2+}$ caused significant reduction of SOD and GSH after 48-h treatment. The reduction could be recovered by the co-treatment of GA and GSH. The reduced GSH levels after the treatments of $\mathrm{Cd}^{2+}$ and $\mathrm{Cu}^{2+}$ were $1.33 \pm 0.20 \mathrm{pmol} / 10^{6}$ cells and $1.54 \pm 0.09 \mathrm{pmol} / 10^{6}$ cells, respectively; which were significantly lower than the values of the untreated control $\left(4.93 \pm 0.32 \mathrm{pmol} / 10^{6}\right.$ cells, $p<0.001$ ). The highest GSH level, $3.00 \pm 0.50 \mathrm{pmol} / 10^{6}$ cells, was obtained after the co-treatment of $287.5 \mu \mathrm{M} \mathrm{Cu}^{2+}$ and $1000 \mu \mathrm{M} \mathrm{GSH}$. The value was also higher than those of the groups co-treated with $42.5 \mu \mathrm{M} \mathrm{Cd}^{2+}$ and $1000 \mu \mathrm{M}$ GSH $\left(2.63 \pm 0.55 \mathrm{nmol} / 10^{6}\right.$ cells $)$. For SOD activities, they were reduced from $1.14 \pm 0.12 \mathrm{U} / 10^{6}$ cells to $0.60 \pm 0.06 \mathrm{U} / 10^{6}$ cells and $0.62 \pm 0.06 \mathrm{U} / 10^{6}$ cells, after the addition of $42.5 \mu \mathrm{M} \mathrm{Cd}^{2+}$ and $287.5 \mu \mathrm{M}$ $\mathrm{Cu}^{2+}(p<0.001)$, respectively. The values could be recovered to the highest at $0.97 \pm 0.12 \mathrm{U} / 10^{6}$ cells after the co-treatment of $287.5 \mu \mathrm{M} \mathrm{Cu}^{2+}$ and $1000 \mu \mathrm{M}$ GSH.

\section{Changes in the apoptosis status}

Accompanying the alterations in cell viability, treatment of $\mathrm{Cd}^{2+}$ and $\mathrm{Cu}^{2+}$ caused significant induction of apoptosis in $\mathrm{CHO}$ cells, as reflected by the dramatic elevation of Annexin V-FITC fluorescence levels (Fig. 4). The fluorescence levels for $10^{6}$ cells were $6347.67 \pm 1149.39$ and $5643.50 \pm 938.28$ after the treatments of $42.5 \mu \mathrm{M}$ $\mathrm{Cd}^{2+}$ and $287.5 \mu \mathrm{M} \mathrm{Cu}^{2+}$, respectively. The values were much higher than that of the control group, which was $2503.05 \pm 407.40(p<0.001)$. The fluorescence could be largely reduced by the addition of GA and GSH. The lowest value was $2116.67 \pm 364.52$, which occurred after the cotreatment of $287.5 \mu \mathrm{M} \mathrm{Cu}^{2+}$ and $1000 \mu \mathrm{M} \mathrm{GSH}$.

\section{Altered gene expressions of anti-oxidative stress enzymes}

As the inner mechanism for the detoxification effects of GA and GSH, gene expressions of gst, sod, cat, and ho-1 were detected (Fig. 5). As a result, downregulations of gst and sod were noticed after the treatment of $\mathrm{Cd}^{2+}$ or $\mathrm{Cu}^{2+}$, but they were recovered or even induced to a higher extent after the addition of GA/GSH. Although ho-1 was unaffected by $\mathrm{Cd}^{2+}$ or $\mathrm{Cu}^{2+}$, its expressions were still induced by the addition of GA and GSH. These inductions were in a concentration-dependent manner, and the most obvious induction was found in ho- 1 after the cotreatment of $42.5 \mu \mathrm{M} \mathrm{Cd}^{2+}$ and $1000 \mu \mathrm{M} \mathrm{GSH}$, which was $8.50 \pm 0.71$ folds of the control group level. For gst and sod, their expressions were respectively reduced to $24.02 \%$ and $39.51 \%$ of the control group after the treatment of $42.5 \mu \mathrm{M} \mathrm{Cd}^{2+}$, but the values increased to $3.74 \pm 0.69$ and $2.24 \pm 0.60$ folds of the control group after the co-treatment of $42.5 \mu \mathrm{M} \mathrm{Cd}^{2+}$ and $1000 \mu \mathrm{M}$ GSH. After the treatment of $287.5 \mu \mathrm{M} \mathrm{Cu}^{2+}$, the expressions of gst and sod were reduced to $36 \%$ and $41 \%$ of the control group values, respectively. These values increased to $2.07 \pm 0.33$ and $3.90 \pm 0.81$ folds of the control 

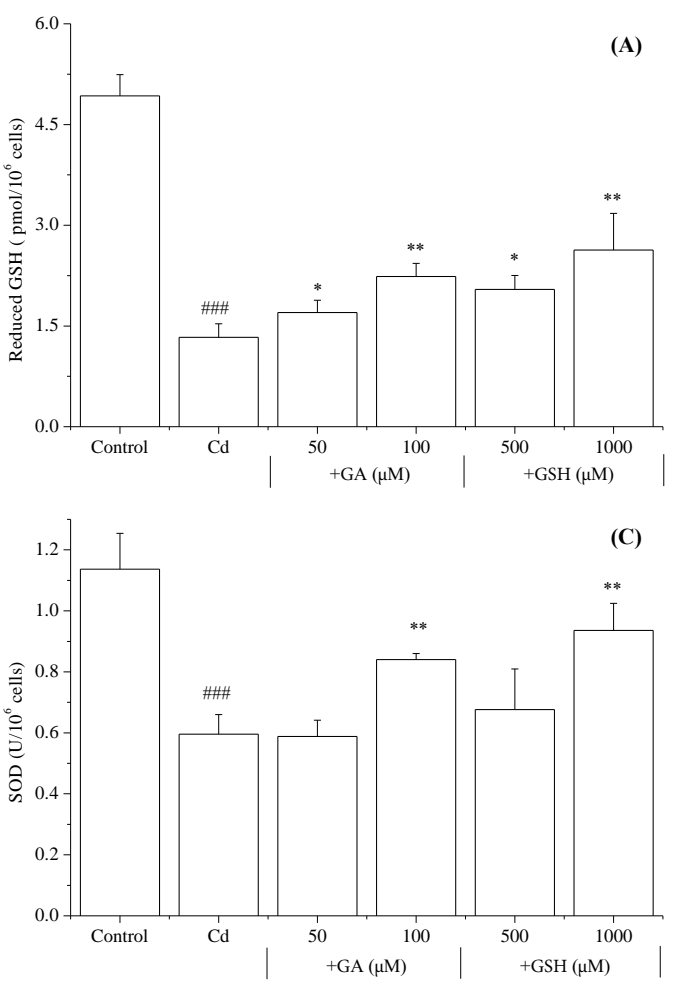
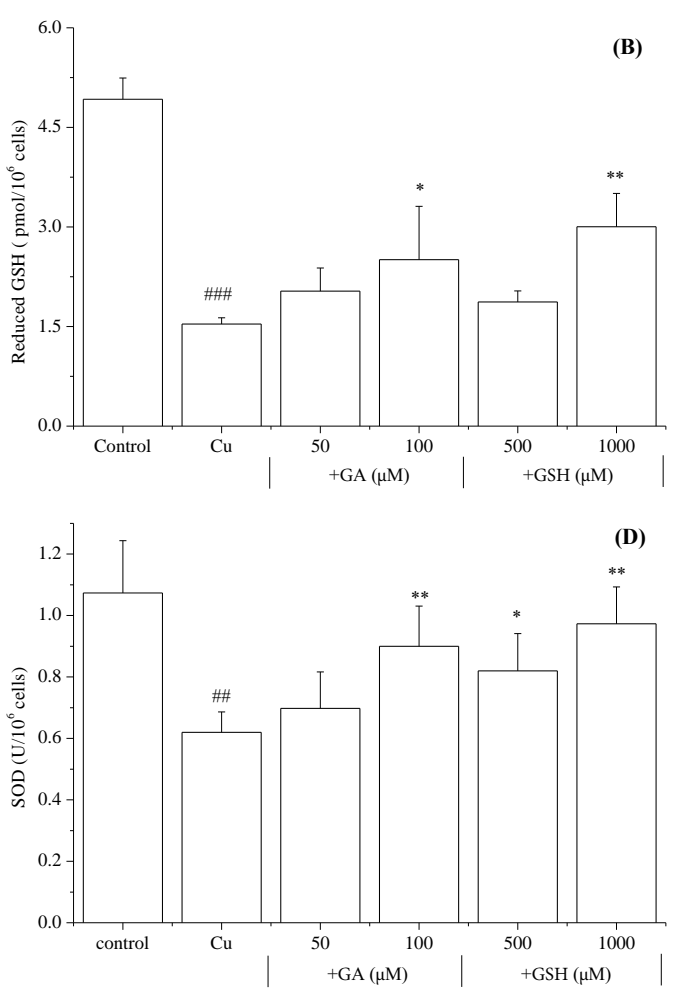

Fig. 3 Effects of GA and GSH on metal ions-induced reduction of GSH and SOD in CHO cells. GA and GSH were added together with metal ions, and the reduced GSH levels and the SOD activities were recorded at $48 \mathrm{~h}$ with commercial kits. Data were represented as mean values \pm SD of three independent experiments. ${ }^{\# \#} p<0.01$, ${ }^{\# \#} p<0.001$ compared with untreated control. ${ }^{*} p<0.05,{ }^{* *} p<0.01$ compared with groups treated by metal ions alone.

groups after the addition of $1000 \mu \mathrm{M}$ GSH. Finally, only the expressions of cat were unaltered after the treatment of either metal ions or metal ionsGA/GSH mixtures.

\section{DISCUSSION}

Supplementation with GA has been proved to be useful in reducing the toxicity of clinical drugs like methotrexate and cocklebur [10,27], but its applicability in the treatment of metal ions-induced toxicity has not been verified. In this respect, this study used $\mathrm{CHO}$ cells to investigate the effects of GA on the reproductive toxicity of $\mathrm{Cu}^{2+}$ and $\mathrm{Cd}^{2+}$, with $\mathrm{GSH}$ as a positive control.

Both $\mathrm{Cd}^{2+}$ and $\mathrm{Cu}^{2+}$ caused significant reduction of cell viability in $\mathrm{CHO}$ cells, and the toxicity could be eliminated by the co-treatment of GSH and GA (Figs. 1 and 2). Although the toxicity of metal ions has been attributed to various elements like disruption of cell membrane, damages of DNA, dysfunction of mitochondrial, as well as endoplasmic reticulum stress, induction of oxidative stress is the most widely-accepted reason $[28,29]$.
In response to such toxicity, production of GSH is elevated to eliminate metal ions-induced reactive oxygen species (ROS) [30]. Therefore, the protective effects of oxidative stress scavenger like GA and GSH are reasonable (Fig. S1) [10,31]. To further explore the involving mechanism, GSH levels, SOD activities, apoptosis status, and the gene expressions of anti-oxidative stress enzymes (including gst, sod, cat, and ho-1) were evaluated, after the treatment of $\mathrm{Cd}^{2+} / \mathrm{Cu}^{2+}$ with or without GA/GSH.

At first, the protective effects of GA and GSH were reflected by the recovering of anti-oxidative function in $\mathrm{CHO}$ cells (Fig. 3). So far, glutathione S-transferase conjugation of GSH was believed to be important in the detoxification of $\mathrm{Cd}^{2+}$ and $\mathrm{Cu}^{2+}$ in vitro and in vivo $[32,33]$. Meanwhile, SOD was involved in the elimination of ROS produced by metal ions $[17,34]$. However, when the concentrations of $\mathrm{Cd}^{2+}$ and $\mathrm{Cu}^{2+}$ were high beyond the capacity of these enzymes, severe cell death and reduction of these enzymes were found [35]. In this respect, the elevation of GSH and SOD could be considered as the recovering of self-protective 

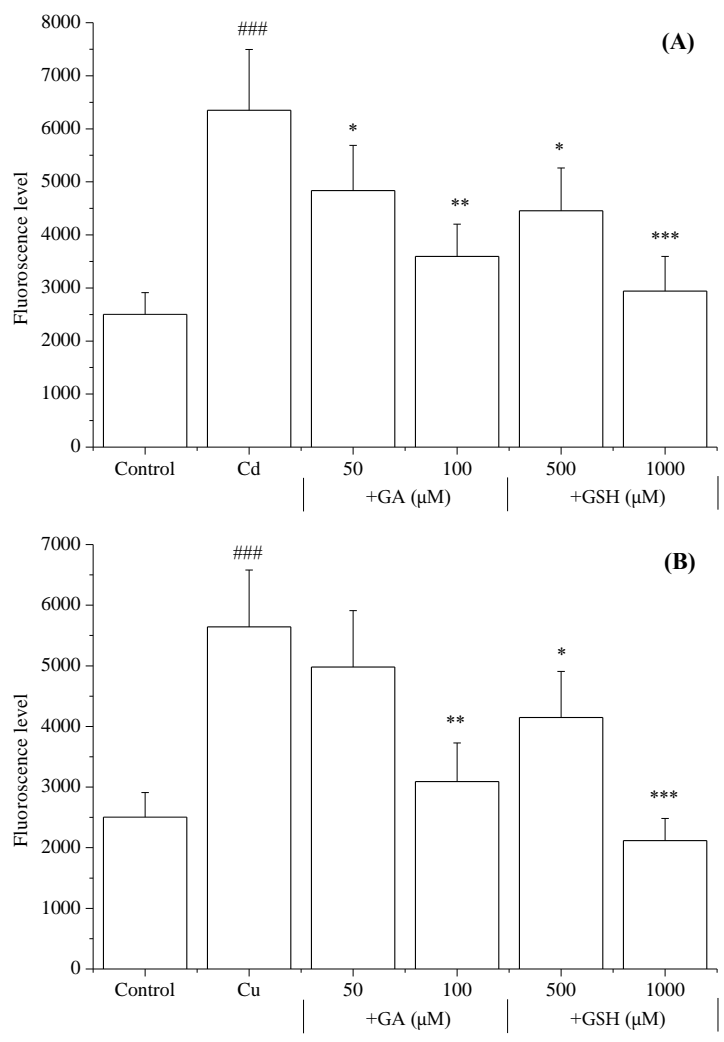

Fig. 4 Effects of GA and GSH on metal ions-induced apoptosis in CHO cells. GA and GSH were added together with metal ions, and the apoptosis status was recorded at $48 \mathrm{~h}$ with commercial kits. Data were represented as mean values $\pm S D$ of three independent experiments. \#\#\# $p<0.001$ compared with untreated control. * $p<$ $0.05, * * p<0.01, * * * p<0.001$ compared with groups treated by metal ions alone.

functions, which could be a novel finding for the protective functions of GA. More importantly, GA exhibited a comparable detoxification effects even at much lower concentrations than GSH (50-100 $\mu \mathrm{M}$ v.s $500-1000 \mu \mathrm{M}$ ), indicating a fact that more inner mechanisms remained to be elucidated.

Secondly, apoptosis was found to play an important role in the toxicity of metal ions, which was also largely reduced by the co-treatment of GA and GSH (Fig. 4). Such phenomena could be explained by the elevation of GSH and SOD activities. Although the reproductive toxicity of metal ions has been widely reported $[10,36]$, their relationship with apoptosisinducing effects are still rare. Our study not only confirmed the role of apoptosis in the reproductive toxicity of $\mathrm{Cd}^{2+}$ and $\mathrm{Cu}^{2+}$, but also showed that GA and GSH could reduce such toxicity by preventing
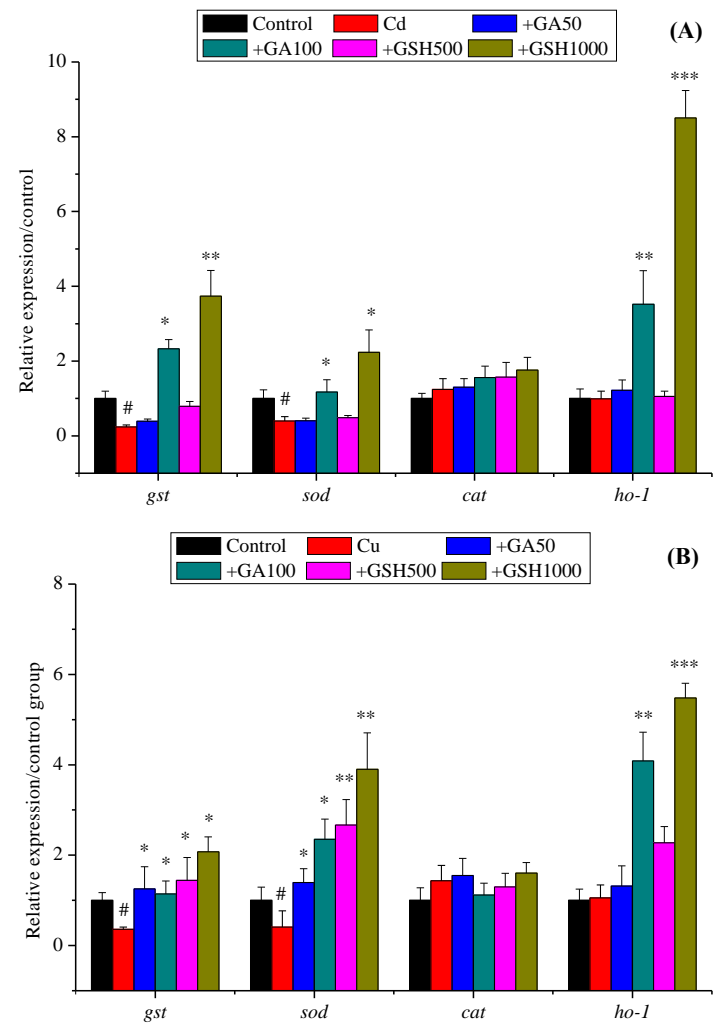

Fig. 5 Altered gene expressions of anti-oxidative stress enzymes including gst, cat, sod, and ho-1 after the treatments of $\mathrm{Cd}^{2+} / \mathrm{Cu}^{2+}$ with or without GA/GSH. Gene expressions were detected with RT-PCR and expressed as the average values of three independent experiments. ${ }^{\#} p<0.05$ compared with untreated control. ${ }^{*} p<0.05$, $* * p<0.01$, $* * * p<0.001$ compared with groups treated by metal ions alone.

the occurrence of apoptosis in $\mathrm{CHO}$ cells.

Finally, treatments of GA and GSH induced the expressions of gst, sod, and ho-1, which could be another reason for the protective effects of the two reducing reagents (Fig. 5). Enzymes, including Gst, SOD, and Ho-1, have been widely accepted as antioxidative enzymes, which help in the defense of ROS in living organisms $[16,17,23]$. Therefore, the induction of these anti-antioxidative stress enzymes suggested a promotion of self-protection function in $\mathrm{CHO}$ cells. In addition, elevation of gst could be caused by the supplement of GSH from the treatment of GA and GSH, which could also be a partial reason for the induction of sod and ho-1 [20]. Again, GA exhibited a comparable effect with GSH, although at much lower concentrations. 


\section{CONCLUSION}

The results of this study indicated significant protective effects of GA on the toxicity of $\mathrm{Cu}^{2+}$ and $\mathrm{Cd}^{2+}$ in CHO cells. These effects were like GSH, occurring due to the promotion of anti-oxidative function. Such phenomenon needs confirmation from in vivo experiments. Moreover, efforts would be taken to screen more useful herbal medicines for reducing the reproductive toxicity of metal ions.

\section{Appendix A. Supplementary data}

Supplementary data associated with this article can be found at http://dx.doi.org/10.2306/ scienceasia1513-1874.2021.052.

Acknowledgements: This work was supported by the Suzhou Key Medical Center (No. SZZX201505), Suzhou Introduced Project of Clinical Medical Expert Team (No. SZYJTD201708), Natural Science Foundation of Shandong Province (No. ZR2019QB021), and Innovation Project of Suzhou Institute of Biomedical Engineering and Technology, Chinese Academy of Sciences (No. Y95P061P05).

\section{REFERENCES}

1. Li L, Holm PE, Marcussen H, Bruun Hansen HC (2014) Release of cadmium, copper and lead from urban soils of Copenhagen. Environ Pollut 187, 90-97.

2. Mania M, Szynal T, Rebeniak M, Postupolski J (2018) Exposure assessment to lead, cadmium, zinc and copper released from ceramic and glass wares intended to come into contact with food. Rocz Panstw Zakl Hig 69, 405-411.

3. Lu Q, Zhang T, Zhang W, Su C, Yang Y, Hu D, Xu Q (2018) Alleviation of cadmium toxicity in Lemna minor by exogenous salicylic acid. Ecotoxicol Environ Saf 147, 500-508.

4. Cao R, Zhang T, Li X, Zhao Y, Wang Q, Yang D, Qu Y, Liu H, et al (2019) Seawater acidification increases copper toxicity: A multi-biomarker approach with a key marine invertebrate, the Pacific Oyster Crassostrea gigas. Aquat Toxicol 210, 167-178.

5. Tian J, Hu J, Chen M, Yin H, Miao P, Bai P, Yin J (2017) The use of mrp1-deficient (Danio rerio) zebrafish embryos to investigate the role of Mrp1 in the toxicity of cadmium chloride and benzo[a]pyrene. Aquat Toxicol 186, 123-133.

6. Li Y, Kang ZL, Qiao N, Hu LM, Ma YJ, Liang XH, Liu JL, Yang ZM (2017) Effects of excess copper ions on decidualization of human endometrial stromal cells. Biol Trace Elem Res 177, 10-15.

7. Suwanpraserta S, Saenphetb S, Buncharoenb W, Kullasootc S, Sareeinc N, Phalarakshb C (2020) Effects of cadmium on acetylcholinesterase activities and histopathology of African catfish (Clarias gariepinus) from contaminated fish farm in Mae Sot District, Tak Province, Thailand. ScienceAsia 46, 611-618.

8. Drag-Kozak E, Socha M, Gosiewski G, LuszczekTrojnar E, Chyb J, Popek W (2018) Protective effect of melatonin on cadmium-induced changes in some maturation and reproductive parameters of female Prussian carp (Carassius gibelio B.). Environ Sci Pollut Res 25, 9915-9927.

9. Mouro VGS, Martins ALP, Silva J, Menezes TP, Gomes MLM, Oliveira JA, Melo F, Matta SLP (2019) Subacute testicular toxicity to cadmium exposure intraperitoneally and orally. Oxid Med Cell Longev 2019, ID 3429635.

10. Espart A, Artime S, Tort-Nasarre G, Yara-Varon E (2018) Cadmium exposure during pregnancy and lactation: materno-fetal and newborn repercussions of Cd(ii), and Cd-metallothionein complexes. Metallomics 10, 1359-1367.

11. Wang L, Li P, Wen Y, Yang Q, Zhen L, Fu J, Li Y, Li S, et al (2018) Vitamin C exerts novel protective effects against cadmium toxicity in mouse spermatozoa by inducing the dephosphorylation of dihydrolipoamide dehydrogenase. Reprod Toxicol 75, 23-32.

12. Samuel JB, Stanley JA, Princess RA, Shanthi P, Sebastian MS (2011) Gestational cadmium exposureinduced ovotoxicity delays puberty through oxidative stress and impaired steroid hormone levels. $J$ Med Toxicol 7, 195-204.

13. Fu Y, Jia FB, Wang J, Song M, Liu SM, Li YF, Liu SZ, Bu QW (2014) Effects of sub-chronic aluminum chloride exposure on rat ovaries. Life Sci 100, 61-66.

14. Dong F, Li J, Lei WL, Wang F, Wang Y, Ouyang YC, Hou Y, Wang ZB, et al (2020) Chronic cadmium exposure causes oocyte meiotic arrest by disrupting spindle assembly checkpoint and maturation promoting factor. Reprod Toxicol 96, 141-149.

15. Akinola AO, Oyeyemi AW, Daramola OO, Raji Y (2020) Effects of the methanol root extract of Carpolobia lutea on sperm indices, acrosome reaction, and sperm DNA integrity in cadmium-induced reproductive toxicity in male Wistar rats. JBRA Assist Reprod 24, 454-465.

16. Ahmad I, Shukla S, Singh D, Chauhan AK, Kumar V, Singh BK, Patel DK, Pandey HP, et al (2014) CYP2E1mediated oxidative stress regulates HO-1 and GST expression in maneb- and paraquat-treated rat polymorphonuclear leukocytes. Mol Cell Biochem 393, 209-222.

17. Liao J, Yang F, Chen H, Yu W, Han Q, Li Y, Hu L, Guo J, et al (2019) Effects of copper on oxidative stress and autophagy in hypothalamus of broilers. Ecotoxicol Environ Saf 185, ID 109710.

18. Jiang M, Huang L, Gu X, Liu T, Kang J, Wang T (2019) Traditional Chinese herb for low endometrial receptivity and its effect on pregnancy: Protocol for a systematic review and meta-analysis. Medicine (Bal- 
timore) 98, e17841.

19. Jazani AM, Hamdi K, Tansaz M, Nazemiyeh $H$, Bazargani HS, Fazljou SMB, Azgomi RND (2018) Herbal medicine for oligomenorrhea and amenorrhea: a systematic review of ancient and conventional medicine. Biomed Res Int 2018, ID 3052768.

20. Altinkaynak Y, Kural B, Akcan BA, Bodur A, Ozer S, Yulug E, Mungan S, Kaya C, et al (2018) Protective effects of L-theanine against doxorubicin-induced nephrotoxicity in rats. Biomed Pharmacother 108, 1524-1534.

21. Yang H, Kim HJ, Pyun BJ, Lee HW (2018) Licorice ethanol extract improves symptoms of polycytic ovary syndrome in letrozole-induced female rats. Integr Med Res 7, 264-270.

22. Umar SA, Tanveer MA, Nazir LA, Divya G, Vishwakarma RA, Tasduq SA (2019) Glycyrrhizic acid prevents oxidative stress mediated DNA damage response through modulation of autophagy in ultraviolet-B-irradiated human primary dermal fibroblasts. Cell Physiol Biochem 53, 242-257.

23. Hu L, Tian $\mathrm{K}$, Zhang $\mathrm{T}$, Fan $\mathrm{CH}$, Zhou P, Zeng D, Zhao S, Li LS, et al (2019) Cyanate induces oxidative stress injury and abnormal lipid metabolism in liver through Nrf2/HO-1. Molecules 24, ID 3231.

24. Ju SM, Kim MS, Jo YS, Jeon YM, Bae JS, Pae HO, Jeon BH (2017) Licorice and its active compound glycyrrhizic acid ameliorates cisplatin-induced nephrotoxicity through inactivation of p53 by scavenging ROS and overexpression of $\mathrm{p} 21$ in human renal proximal tubular epithelial cells. Eur Rev Med Pharmacol Sci 21, 890-899.

25. Thayumanavan $P$, Loganathan C, Iruthayaraj A, Poomani K, Nallaiyan S (2018) S-allyl-glutathione, a synthetic analogue of glutathione protected liver against carbon tetrachloride toxicity: Focus towards anti-oxidative efficiency. Environ Toxicol Pharmacol 58, 21-28.

26. Yin J, Yang JM, Zhang F, Miao P, Lin Y, Chen ML (2014) Individual and joint toxic effects of cadmium sulfate and alpha-naphthoflavone on the development of zebrafish embryo. $J$ Zhejiang Univ Sci B 15, 766-775.

27. Cao Y, Shi H, Sun Z, Wu J, Xia Y, Wang Y, Wu Y, Li
X, et al (2019) Protective effects of magnesium glycyrrhizinate on methotrexate-induced hepatotoxicity and intestinal toxicity may be by reducing COX-2. Front Pharmacol 10, ID 119.

28. Hu J, Tian J, Zhang F, Wang H, Yin J (2019) Pxrand Nrf2- mediated induction of ABC transporters by heavy metal ions in zebrafish embryos. Environ Pollut 255, ID 113329.

29. Mostafa DG, Khaleel EF, Badi RM, Abdel-Aleem GA, Abdeen HM (2019) Rutin hydrate inhibits apoptosis in the brains of cadmium chloride-treated rats via preserving the mitochondrial integrity and inhibiting endoplasmic reticulum stress. Neurol Res 41, 594-608.

30. Liu HJ, Wang X, Yang ZL, Ren LL, Qian TT (2020) Identification and biochemical characterization of the glutathione reductase family from Populus trichocarpa. Plant Sci 294, ID 110459.

31. Hu J, Chen L, Yin J, Yin H, Huang Y, Tian J (2020) Hyperactivity, memory defects, and craniofacial abnormalities in zebrafish fmr1 mutant larvae. Behav Genet 50, 152-160.

32. Salazar-Medina AJ, Garcia-Rico L, Garcia-Orozco KD, Valenzuela-Soto E, Contreras-Vergara CA, Arreola R, Arvizu-Flores A, Sotelo-Mundo RR (2010) Inhibition by $\mathrm{Cu}^{2+}$ and $\mathrm{Cd}^{2+}$ of a mu-class glutathione S-transferase from shrimp Litopenaeus vannamei. $J$ Biochem Mol Toxicol 24, 218-222.

33. Atli G (2020) How metals directly affect the antioxidant status in the liver and kidney of Oreochromis niloticus? An in vitro study. J Trace Elem Med Biol 62, ID 126567.

34. Turan F, Eken M, Ozyilmaz G, Karan S, Uluca H (2020) Heavy metal bioaccumulation, oxidative stress and genotoxicity in African catfish Clarias gariepinus from Orontes river. Ecotoxicology 29, 1522-1537.

35. Qin Y, Li X, Yang Y, Li Z, Liang Y, Zhang X, Jiang S (2018) Toxic effects of copper sulfate on diploid and triploid fin cell lines in Misgurnus anguillicaudatus. Sci Total Environ 643, 1419-1426.

36. Adam N, Vakurov A, Knapen D, Blust R (2015) The chronic toxicity of $\mathrm{CuO}$ nanoparticles and copper salt to Daphnia magna. J Hazard Mater 283, 416-422. 


\section{Appendix A. Supplementary data}

Table S1 Primers used in this experiment.

\begin{tabular}{|c|c|c|c|c|}
\hline & & Primer $\left(5^{\prime}-3^{\prime}\right)$ & Product size (bp) & Reference \\
\hline$\beta$-actin & $\begin{array}{l}\text { Forward } \\
\text { Reverse }\end{array}$ & $\begin{array}{l}\text { TCTTTCTTCGCCGCTCCAC } \\
\text { GTAGGAGTCCTTCTGGCCCAT }\end{array}$ & 196 & XM_007648665.3 \\
\hline gst & $\begin{array}{l}\text { Forward } \\
\text { Reverse }\end{array}$ & $\begin{array}{l}\text { GGACTTCTTGGCACGCTTTG } \\
\text { GTCACAGAGCCACACCTGAG }\end{array}$ & 186 & XM_003514942.4 \\
\hline cat & $\begin{array}{l}\text { Forward } \\
\text { Reverse }\end{array}$ & $\begin{array}{l}\text { CGATTTCTTACCCCGGGTGG } \\
\text { GTGGTCAGGACATCGGGTTT }\end{array}$ & 167 & XM_003497440.4 \\
\hline sod & $\begin{array}{l}\text { Forward } \\
\text { Reverse }\end{array}$ & $\begin{array}{l}\text { GACTGACTGAAGGCCAGCAT } \\
\text { CAGTCACATTGCCCAGGTCT }\end{array}$ & 156 & XM_007642000.1 \\
\hline ho-1 & $\begin{array}{l}\text { Forward } \\
\text { Reverse }\end{array}$ & $\begin{array}{l}\text { GCATAGCCGGGAGCCTAAAG } \\
\text { GCCTGGATATGCACCTCCTT }\end{array}$ & 141 & XM_003511957.4 \\
\hline
\end{tabular}

Specific primers for each gene were designed with Primer Premier 5.0 software (Premier Biosoft Inc., Palo Alto, CA, USA).
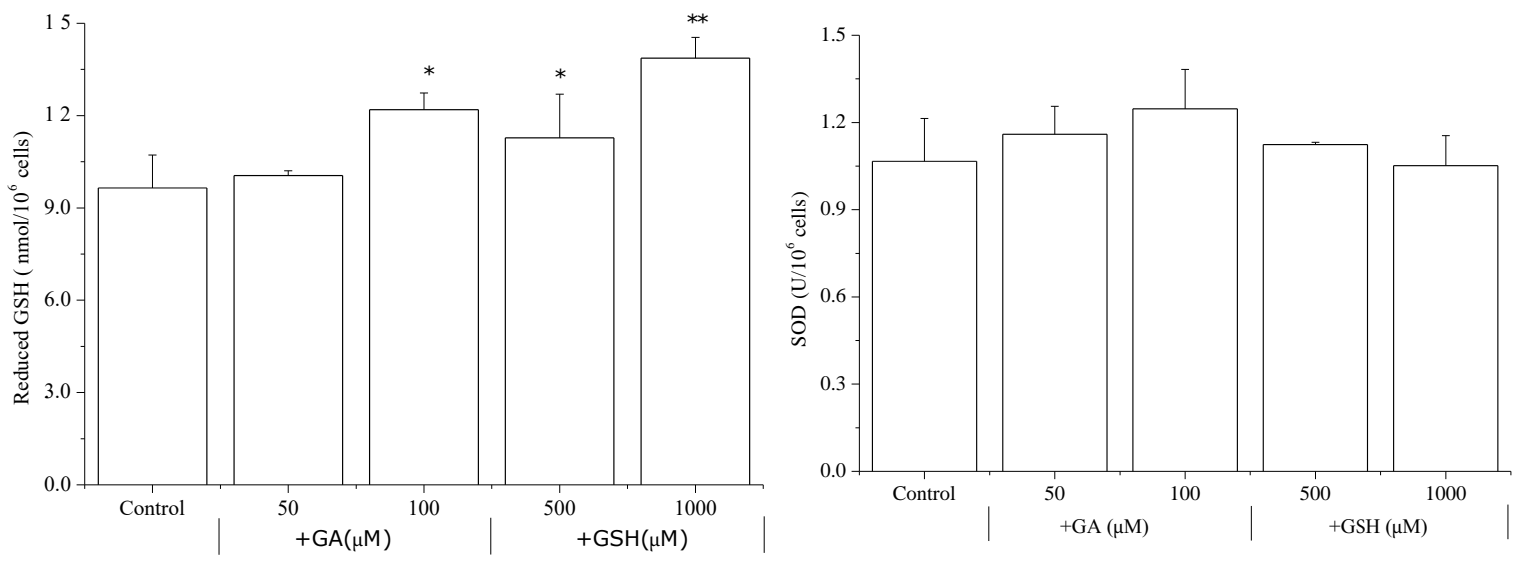

Fig. S1 Effects of GA/GSH treatments on the GSH and SOD levels of CHO cells. Data were represented as mean values \pm SD of three independent experiments. ${ }^{*} p<0.05,{ }^{* *} p<0.01$ compared with untreated control. 